\title{
Comparison of the clinical characteristics and treatment outcomes of patients requiring hospital admission to treat eosinophilic and neutrophilic exacerbations of COPD [Corrigendum]
}

Kang HS, Rhee CK, Kim SK, Kim JW, Lee SH, Yoon HK, Ahn JH, Kim YH. Int J Chron Obstruct Pulmon Dis. 2016;11:2467-2473.

Page 2467, Abstract, Results section, line 1, the text "COPD exacerbations (177 eosinophilic and 380 neutrophilic) were included" should read "COPD exacerbations (177 eosinophilic, 380 neutrophilic and 48 paucigranulocytic) were included. Of these, we compared patients with eosinophilic and neutrophilic COPD exacerbations".

\section{Publish your work in this journal}

The International Journal of COPD is an international, peer-reviewed journal of therapeutics and pharmacology focusing on concise rapid reporting of clinical studies and reviews in COPD. Special focus is given to the pathophysiological processes underlying the disease, intervention programs, patient focused education, and self management protocols.
Dovepress

This journal is indexed on PubMed Central, MedLine and CAS. The manuscript management system is completely online and includes a very quick and fair peer-review system, which is all easy to use. Visit http://www.dovepress.com/testimonials.php to read real quotes from published authors. 